\title{
Article \\ SIMILARITY IN SYMMETRY GROUPS OF ORNAMENTS AS A MEASURE FOR CULTURAL INTERACTIONS IN MEDIEVAL TIMES
}

\author{
Mehmet Erbudak 1,,$* *$ 00000-0002-6316-5115 and Selim Onat $2, \mp \oplus 0000-0002-4782-5603$ \\ 1 Department of Physics, ETHZ, CH-8093 Zurich, Switzerland; erbudak@phys.ethz.ch \\ 2 Free Now Tech, Data Science, D-22767 Hamburg, Germany; selim.onat@free-now.com \\ * Correspondence: erbudak@phys.ethz.ch \\ $\ddagger$ These authors contributed equally to this work. \\ Received: date; Accepted: date; Published: date
}

\begin{abstract}
The symmetry properties of an ornament contain information about its civilisation and its interactions with other cultural sources. Two-dimensional periodic ornaments can be strictly classified into a limited set of 17 mathematical symmetry groups, also known as wallpaper groups. The collection of ornaments thus classified for a civilisation is characteristic of the cultural group and serves as a fingerprint to identify that group. If the distribution of wallpaper groups is available for several societies, mathematical methods can be applied to determine similarities and differences between the art practices of these communities. This method allows a systematic approach to the general ornamental practices within a culture and their interactions in the form of similarity of fingerprints. We test the feasibility of the method on examples of medieval Armenians, Byzantium, Seljuks first in Persia and then in Anatolia and among Arabs in the Middle East. For this purpose we present the distribution of the planar ornaments and calculate the Euclidean distances in pairs. We tested to what extend geographical and religious factors could account for the observed similarity of ornamental groups between cultures. The results suggest an intensive interaction between the Seljuk Turks and Arab craftsmen who produced the ornaments. Therefore the cultural interactions are religiously motivated.
\end{abstract}

Keywords: wallpaper groups; planar ornaments; Euclidean distance; multi-dimensional scaling; Arabs; Armenian; Byzantium; Islam; Seljuks; cultural interaction

\section{Introduction}

Symmetry was first used about 80 years ago to bring to light some fascinating properties of works of art. These were two-dimensional, periodic ornaments, which were described according to their point-group and translational symmetries. The novel achievement was to establish the 17 wallpaper groups within group theory. This kind of categorisation made it possible to extract invariant characteristics of artworks that seemed to be very different on a perceptual level. Responsible for this development were Georg Pólya [1], Andreas Speiser [2] and Edith A. Müller [3], who contributed to the characterisation of wallpapers, floor ornaments and textiles, just as the crystallographers studied the surface atomic positions [4]. During these years Maurits Cornelis Escher also drew inspiration from the 17 planar symmetry groups in his creations [5].

More than a quarter of a century passed before scientists applied the idea of wallpaper characterisation of planar patterns to products of different civilisations [6]. The goal of such efforts is motivated by the question whether the use of symmetries of patterns and their distribution across the 17 wallpaper groups is characteristic of the culture that created them. If so, this knowledge could be used to determine the origins of the craftsmen and cultural interactions. One hypothesis, for example, is that the more cultural relations and exchanges between civilisations are frequent, the more similar the artworks created by these civilisations might be, and therefore the more similar the categories of 
wallpaper. However, the main efforts have focused on questioning Müller's pioneering work and analysing other Islamic patterns.

Recently, we have applied these symmetry considerations to the floor ornaments of the St. Mark's Cathedral in Venice [7]. This cathedral is a monument of another civilisation besides the Muslim world, namely a creation of the Eastern Roman Empire with a certain Venetian flair. We have found that while fourfold symmetry was by far the most frequently observed group, all other symmetry groups except threefold symmetries were present.

We also analysed Armenian ornaments [8] found on wood, metal, textiles [9], and mostly in the form of stone masonry [10].

More recently, the symmetry properties of the ornaments created by the Seljuk Turks in Anatolia have been the focus of our efforts [11]. At the end of the 10th century the Seljuks moved from Asian prairies to Persian territories and later, with some acquired Persian-Muslim habits, into the countries of the Christian peoples, especially Anatolian Greeks and Armenians. They quickly developed a full-fledged sultanate and erected religious and commercial buildings, which they richly decorated with ornaments.

In this paper we present the symmetry distribution of ornaments created by civilisations originating from nearby areas in the Middle East: Eastern Roman Empire, Arabs in the Middle East, Armenia and Seljuks before and after their settlement in Asia Minor. The works of art we present are from the 9th to the 15th centuries. Our aim is to find dissimilarities in the symmetry distributions of the works of art presented in order to gain insight into the artistic interaction. It is conceivable that artists from these civilisations were mainly influenced by others who share their own religious background and pass on their professional experience according to religious criteria. Alternatively, it is also possible that geographical factors played a more important role in the interaction between different cultures, in addition to cultural borders. To this end, we obtain the dissimilarity relationships between the artworks of these five civilisations through the distributions of wallpaper groups. We visualise the observed dissimilarity relationships calculating the Euclidean distances between all pairs of cultural groups. We use a multi-dimensional scaling (MDS) [12] method and investigate the contributions of geographical distance and commonalities in the religious background. Chapter 2 presents the distribution of symmetry properties of each civilisation together with a rudimentary visual analysis of the data. Chapter 3 outlines our procedures for assessing dissimilarities, applying the novel approach to the data and the extracting dissimilarity functions. Finally, Chapter 4 contains the discussion of our results.

\section{Materials and Methods}

We present the preferences of the ornamental symmetries of five cultures, living in the neighbouring countries of the Middle East between the 9th and 15th century. The ornaments are mainly found on the walls or floors of sacred monuments. They are either inlaid as pieces of carefully prepared marble or masonry on large surfaces or glazed tiles. By visual inspection we can detect all point-group symmetries that determine the ornaments, such as rotations around an axis by $n=1,2,3,4$ or 6 , where $2 \pi / n$ is the angle of rotation, as well as mirror reflections $m$. The wallpaper group is uniquely determined by the translation symmetries. Some groups contain additional glide reflections $g$. This defines the 17 wallpaper groups [1-3]. For each cultural group we analyse the available artefacts, the ornaments, and record the occurrence of the groups. If a pattern occurs several times in different places, we count it only once. Some patterns show interlacing that leads to a three-dimensional appearance. We retain the bands responsible for the interlacing instead of reducing them to simple intersecting lines, while respecting the underlying symmetry. We have taken colours into account, even if this leads to a lower symmetry. 


\subsection{Eastern Roman Empire}

Today's Istanbul is a well-populated metropole, and has been for two millennia [13,14]. It was colonised as Byzantion by the Greeks of Megara in 657 BC. In 196 AD the city was besieged by the Romans for the first time, but Greek has remained the cultural language even until today, albeit with only a few remaining minorities. The city later became Constantinople when the Roman Emperor Constantine I made it his capital in 330 AD.

The Basilica of Agia Sofia was the seat of the Greek Patriarch and thus the centre of Eastern Orthodoxy. The church of the Holy Apostles was the second most important church after Agia Sofia and was consecrated by Constantine I to the Twelve Apostles of Jesus, with the intention of gathering the mortal remains of all the apostles in this church. It was the inspiration for the Cathedral of St. Mark in Venice, which was built according to her plans [15].

It was believed that the Church of the Holy Apostles was linked to the sufferings of Jesus and remained the vault of the treasures donated by the followers of the Church. After all, Constantinople was a rich city, which was the commercial centre of Europe and the Middle East. Both the Holy Apostles and Agia Sofia were the source of gold, silver and gems for other churches in the western part of the Eastern Roman Empire and especially for the churches around Venice. The real catastrophe for Constantinople was the 4th Crusade in 1204, when all treasures were plundered and brought to Venice [16]. Not much was left of the city. When the Ottoman Turks conquered the city in 1453, Agia Sofia was converted into a mosque and the Patriarch moved to the Church of the Holy Apostles. In 1461 the Ottomans destroyed the Church of the Holy Apostles to use it as a source of building material for a mosque in the name of the Turkish conqueror Mehmet II, the Fatih Mosque. After 1555, more than a century after the end of the Empire, historians used as a new name Byzantium instead of Roman Empire [17].
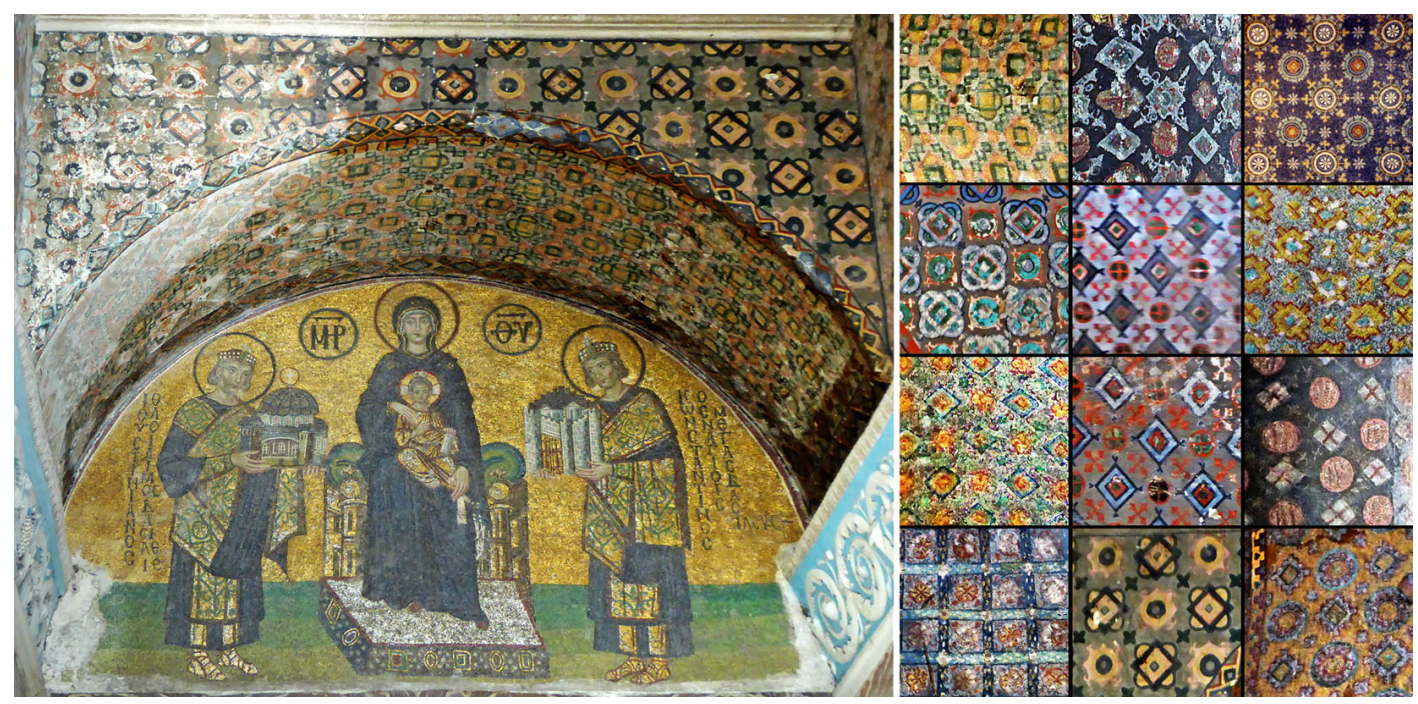

Figure 1. Left: Mother of God and Child, enthroned between the Emperors Constantine I and Justinian I, one of them presents her the city, the other the church of Agia Sofia. Right: Excerpts from the mural paintings of Agia Sofia as they could be seen until recently. Interestingly, they all belong without exception to the symmetry group $4 \mathrm{~mm}$. A wall decoration in the church San Vitale in Ravenna, Italy, which also belongs to the same symmetry group, can be seen in the upper right corner.

We visited Agia Sofia when it was still a museum with different mosaics showing Jesus and/or the Virgin Mary in the middle alone or with emperors on the left and right side. Looking for periodic ornaments, we found that the vestments of four emperors, Alexander, Constantin IX Monomachus, Alexius I Comnenus and John II Comnenus, had golden mosaics with fourfold symmetry $p 4 m m$. Beside the mosaics, there were several wall paintings as decorations. 
Figure 1 shows a mosaic in Agia Sofia on the left, depicting the Virgin Mary with the Child in the center. The tympanum of the mosaic is located above the door leading from the southern vestibule into the narthex. Above and around the mosaic we observe such paintings as planar decorations. A collection of wall paintings can be seen on the right-hand side of the figure. When Agia Sofia was converted into a mosque by the Ottomans, the mosaics and paintings were either destroyed or plastered over. They are exhibited in 1930s, when the mosque became a museum. By removing the plaster and subsequent renovations, the original paintings may have been altered. Nevertheless, we observe a consistent fourfold symmetry in all the exhibited patterns.

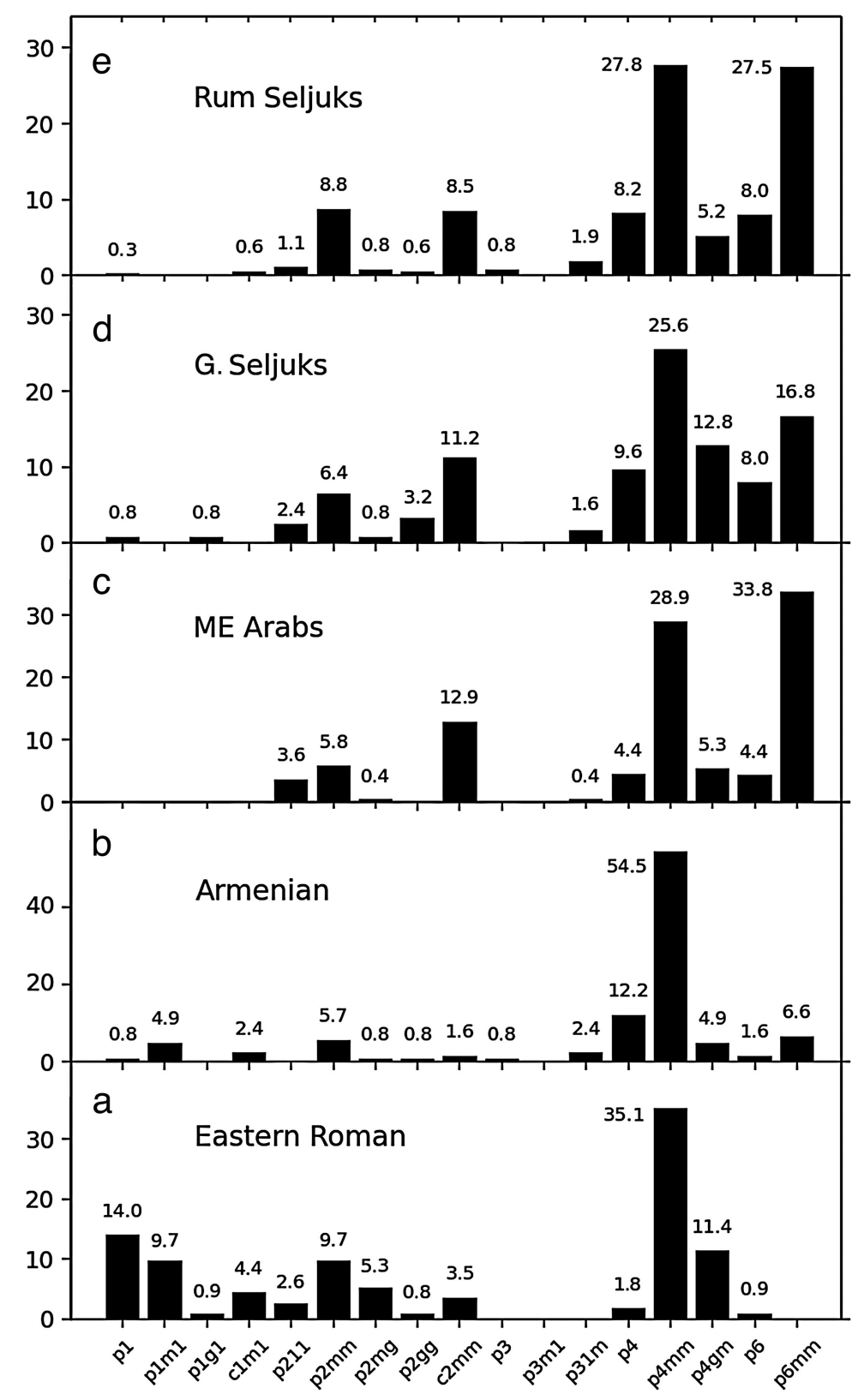

Figure 2. The percentage occurrence of the symmetry groups of the pattern created by a) Eastern Romans (Byzantium), b) the Armenians, c) the Arabs of the Middle East (ME), d) the Great Seljuks in Persia and e) the Seljuk Rum Sultanate.

Considering that the churches in Constantinopel suffered first from total plundering by the Crusades, followed by the Ottoman Islamisation, not much glory can be expected. Instead, we focus on St. Mark's Cathedral in Venice, which is enriched with a considerable amount of treasures from 
Constantinople, at least from Agia Sofia and the Holy Apostles. It is believed that the roots of the cathedral lie in the Church of the Holy Apostles, thus representing a monumental Greek, Roman and Venetian heritage. The cathedral was completed and decorated in its final form over centuries and consecrated for the third time in 1084 [18] Beside the breathtaking mosaics on the walls and domes depicting events from Old and New Testament, the tessellated marble floor is a marvel of craftsmanship [19]. It has aroused great artistic enthusiasm [20], and there exists an extremely valuable archive about the marble floor in the form of orto-photos [21]. We have studied the floor ornaments of St. Mark's Cathedral on the basis of these orto-photos. The frequency of the symmetry groups of the 114 patterns of the marble floor is shown in percent in Figure 2a. No patterns are found with $n=3$ and the group with $n=6$ is quite sparse.

\subsection{Armenians}

Armenia is geographically and thus also politically wedged between the Eastern Roman Empire and the Arab powers [22]. Armenia has already in the year 300 accepted Christianity. Its cultural urge manifests itself by the necessity to have its own script. The Armenian alphabet was developed around 405 by Mesrop Mashtots, an Armenian linguist and church leader. Individual letters are graphically so artistically designed that they are used creatively in the ornamentation [23].

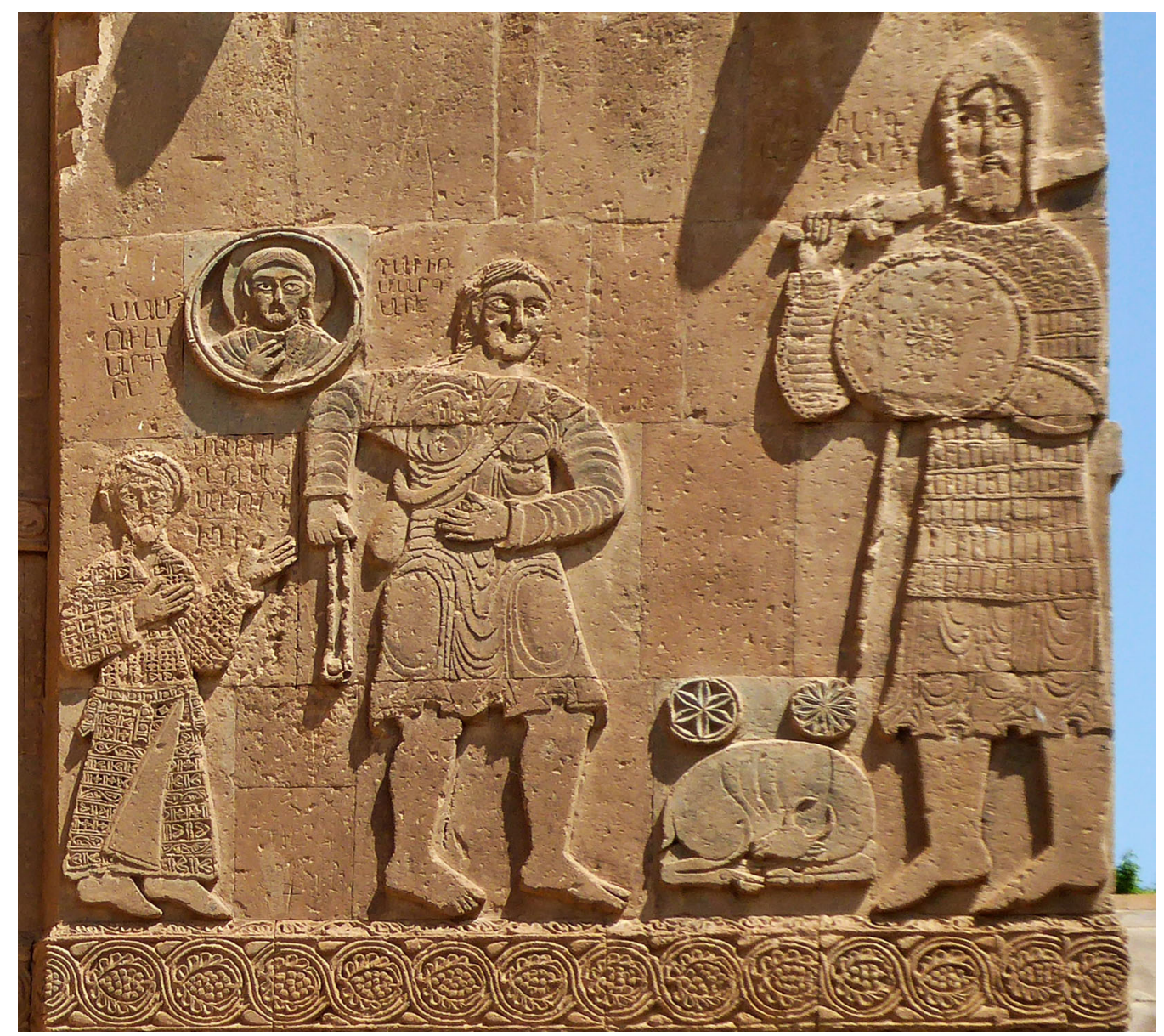

Figure 3. The southeastern façade of the Surp Khatch Church on the island of Akhtamar in Lake Van, Turkey. The entire building is covered with horizontal ornamental bands at various heights, all carved in stone. Here, we see David and Goliath, and the wine freeze beneath their feet.

The Armenians occasionally had good relations with their neighbours. There were mixed marriages with Arabs, and conversion to Islam was not unknown. Some Byzantine Emperors were of Armenian descent. As the attacks of the Great Seljuks from the east intensified, Armenians began 
to move west, to Cappadocia and Cilicia. Several Armenian ornaments originate from these areas [24]. In Armenian masterpieces the creation of sculpture and architecture is harmoniously combined - the stone masonry in sacred monuments and khachkars, the tombstones, is of expressive quality [10]. Khachkars bear a very rich collection of ornaments [25]. Although they have been somewhat destroyed in neighbouring countries, a considerable number of khachkars are exhibited in the open-air museum at the Noratuz Cemetary in Gavar, Armenia.

The Surp Khatch Church on the island of Akhtamar in Lake Van, Turkey, a medieval Armenian sacred building. It was built by the architect Bishop Manuel during the reign of Gagik I Ardzruni (around 915). Rectangular stones of different sizes are used for the construction as a measure against earthquakes. The stone masonry covers all the exterior walls, which, with the reliefs, tell the story of the universe from creation onwards with symbolism and abstraction [22]. Figure 3 shows Saul, first king of Israel, on the left-hand side wearing a cape with regular patterns. To the right side, we see David holding a sling in his right hand. Then comes the giant Goliath, armed with sword and shield. He wears armour consisting of several parts, each of which has an ornament of different symmetry. He carries a shield with two concentric rosettes, the larger one with seventy-two and the smaller one with twelvefold symmetry. Between David and Goliath and above the sleeping deer there are two rosettes with sixfold and twelvefold symmetry.

Figure $2 \mathrm{~b}$ shows the symmetry distribution of 125 medieval ornaments collected by Armen Kyurkchyan on sacred buildings and khachkars in historical Armenia during the last three decades [10]. About half of the collected ornaments have the symmetry group $\mathrm{p} 4 \mathrm{~mm}$ and the rest are almost equally distributed [8].

\subsection{Arabs}

Islam, the last monotheistic religion, was born in 622 in a district around Mekka in today's Saudi Arabia as a revelation for the Prophet Muhammad. Islam acted as a cultural inspiration for the Arabs of the vast desert lands. Besides a spiritual power it gave the Arabs the impetus for the development of organisation, military power, language, progress in science and art [26]. Within a short time the Arabs shared these virtues in the north-east, in Persia, Afghanistan, India and in the northwest up to the Iberian Peninsula. Within less than 80 years, areas between the Atlantic and the Indian Ocean followed Islam. In the West, cultural centres emerged in Andalusia, in the Middle East in Damascus as the capital of the Umayyad dynasty, in Baghdat as the seat of the Abbasids, and in Cairo as the centre of the Fatimid caliphate.

Most of the expert reports [27,28] and popular art books [29] refer to Islamic Art. In this way, all the other cultures such as Persians, Seljuk Turks, Ottomans, Afghans and Indians converted to Islam are considered equally. In this work we want to examine the influence of the Arabs on Armenian, Byzantine and Seljuk works of art. Therefore, in addition to naming this group Arab, we have limited the artefacts to Arabic areas and have restricted the date of origin to 1400. This was easily achieved with the help of the well-organised ornamental tables of Brian Wichmann [30]. Since in the original collection did not take into account the interlacing and colour, we have reclassified some of the patterns.

With the seizure of power by the Abbasid dynasty, Arab culture developed in two branches. While the Abbasids declared Baghdat their capital, the emergence of the Arabs continued also in Damascus and Cairo. The few Umayyad family members who escaped the Abbasid massacre in 750 moved through North Africa to the Iberian Peninsula to found Umayyads of Andalusia, a civilisation that existed until about 1500 .

In the 8th century the Abbasids with the participation of the Syriacs began with the translation of classical Greek writings into Arabic [26]. This act not only preserved Greek culture, but also imported it into Arabic culture. The reasons of the translation movement may be manifold, but it certainly gave the Abbasids a special position in philosophy and science among their neighbours, the Persians, Armenians and the Greek-speaking Eastern Romans. Among other disciplines, geometry achieved a high status because it built a bridge between religious commitment and the material world. The 
Muslim god Allah cannot be represented in the way it is done in Christianity. Allah is spiritual, Allah is everywhere, Allah is on earth and in heavens. So the Arabic ornaments show stars of the sky with the help of geometry. Arab philosophy preaches spiritual unity, which is an expanding abstraction from a single source. This gives the Arabic work the special characteristic of inflation instead of a scattered flat growth to cover an area. Thus the Arabs created their masterpieces, driven by the passion of abstraction, the search for unity and a life in the sky [31,32]. Figure 4 shows a drawing that is intended to unite these ideas of the classical Islamic ornament. This is a small part of a huge unit cell with fourfold symmetry.

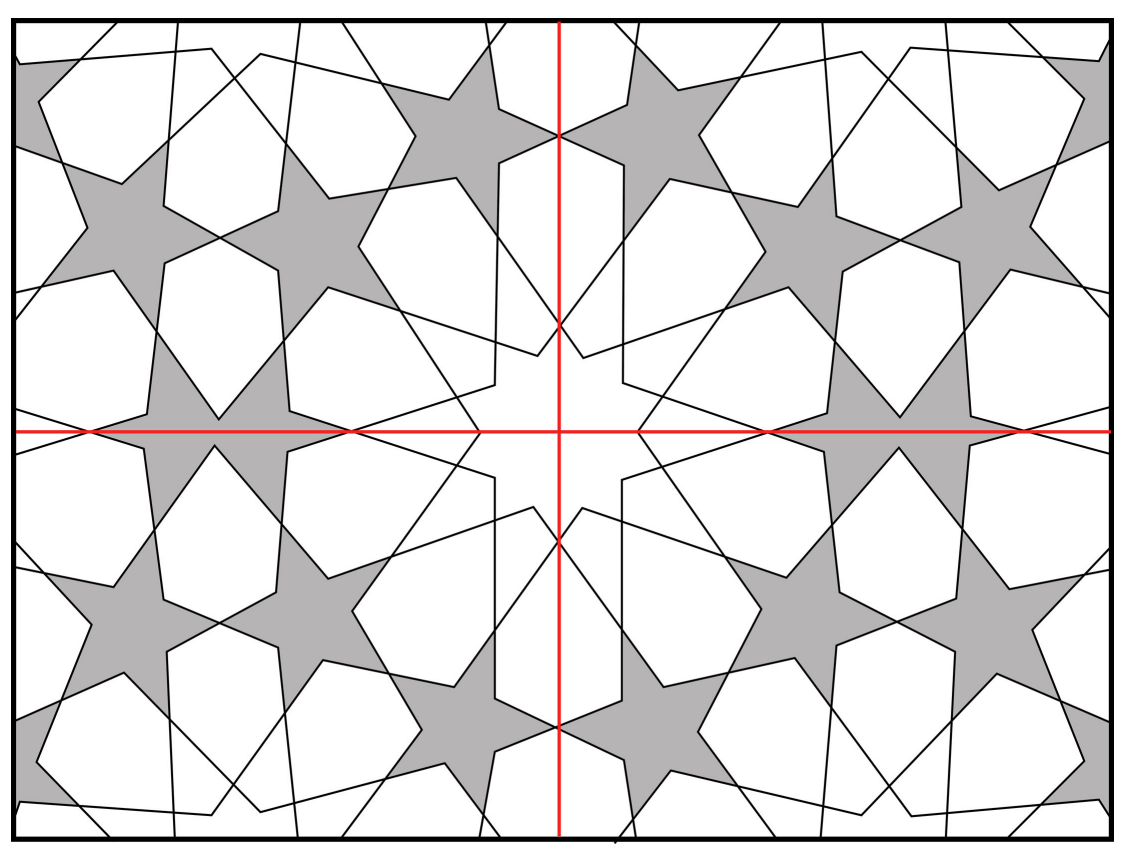

Figure 4. A classic Arabic ornament drawn after a model by Critchlow [32]. Two mirror-reflection lines (red) cross at a twofold-symmetry axis of the pattern.

In the Wichmann Collection we could easily select the artworks created in the Middle East, including Cairo, Baghdat, Damascus, Aleppo and Palestine [30]. Figure 2c is the occurrence of symmetry groups of 226 Arabic ornaments. The complex Islamic patterns prefer polygons with a large number of corners, Which favours a sixfold symmetry. Uniform shapes with mirror symmetries are abundant. In fact, the distribution consists mainly of symmetries of the type $\mathrm{mm}$.

\subsection{The Seljuks}

Seljuks are descendants of Göktürk tribes from the prairies of Central Asia who invaded the Persian territory around $1000[33,34]$. They were already converted to Islam. They conquered all of Iran, including Shiraz and Isfahan, their later capital, and Baghdat, the seat of the Abbasid caliphs. The empire consisted of Turks, who were the best fighters, and the Persians, who were administrative organisers. Seljuk dynasties existed until the Mongol invasions starting the second half of the 13th century.

\subsubsection{The Great Seljuks}

It is not possible to distinguish between Seljuk and Persian creation in architecture and ornamentation, if there is any. Both are strongly influenced by Islam, as they built mosques and minarets in addition to Koran schools and mausoleums, most of which have survived natural disasters to this day.

Figure 5 is a brick decoration of the group $p 4$ found in the Qazvin Mosque, about $150 \mathrm{~km}$ northwest of Tehran in Iran. We have collected Seljuk patterns from various sources $[27,30,33,35,36]$. 
We have considered Wichmann's archives until 1400 [30], and for all sources we have counted the patterns only once, even if they are used in several places. The results from 125 samples are shown in Figure 2d. Great Seljuks preferred ornaments with double-reflection properties, including patterns with sixfold-rotational symmetry. Patterns with fourfold symmetry make up more than half of the patterns.

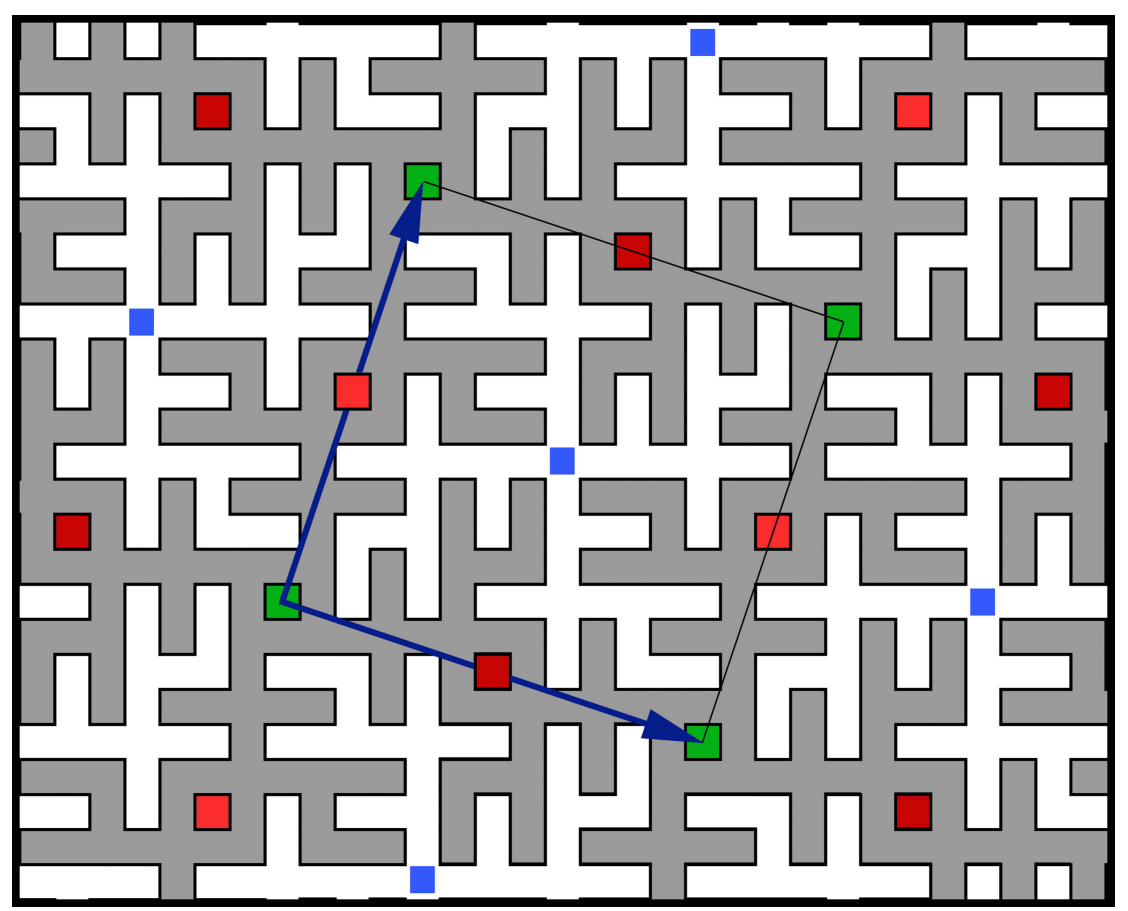

Figure 5. Brick decoration in the Qazvin Mosque, today's Iran. Two different axes of fourfold symmetry are marked blue and green, the twofold axes are red. Translation vectors (dark blue) span the unit cell. The pattern belongs to the symmetry group $p 4$. The abstraction is reproduced from a photograph [33].

\subsubsection{Seljuks of Anatolia}

Figure 6a shows the portal of the Nene Hatun Türbe in Tercan, Erzincan. The remarkable ornaments to the left and right of the entrance door are twofold symmetrical and have mirror reflection properties in two mutually perpendicular directions. Their unit cell is large and contains several different polygons. This type of ornamentation with a large unit cell, as shown in Figure $6 \mathrm{~b}$, is common in the Arab world $[27,28,31,32]$. This observation points to the Arab influence on the Seljuk art. In the Byzantine and Armenian creation we are more likely to find ornaments with a smaller number of elements in the unit cell, as the example in Figure 6c shows. In his unique work, Gerd Schneider [37] classifies Seljuk-Rum artworks according to their graphic characteristics and cleverly distinguishes between the ornaments of the small unit cell and the ornaments of the large unit cell. A comprehensive inventory of the Rum Seljuk art was recently published [40], using a similar typologic classification.

Recently, we have used this extensive collection and classified the ornaments of the Anatolian Seljuks into 17 wallpaper groups [11] taking into account all occurrences. In order to maintain compatibility with the classification of neighbouring cultures, we count each pattern as one, even if it occurs in different places. The results of 364 ornaments are presented in Figure 2e. From the distribution we can see that Seljuks preferred to use holohedral ornaments with double-reflection properties $m m$.

The Anatolian Rum Sultanate of the Seljuk dynasty begins with Nicaea as its capital in 1081 and continues until 1243, when the Mongols take power in Anatolia [38]. Michael Meinecke assigns the dates 1200 to about 1400 to the construction of Seljuk monuments at different places in Anatolia [39]. 


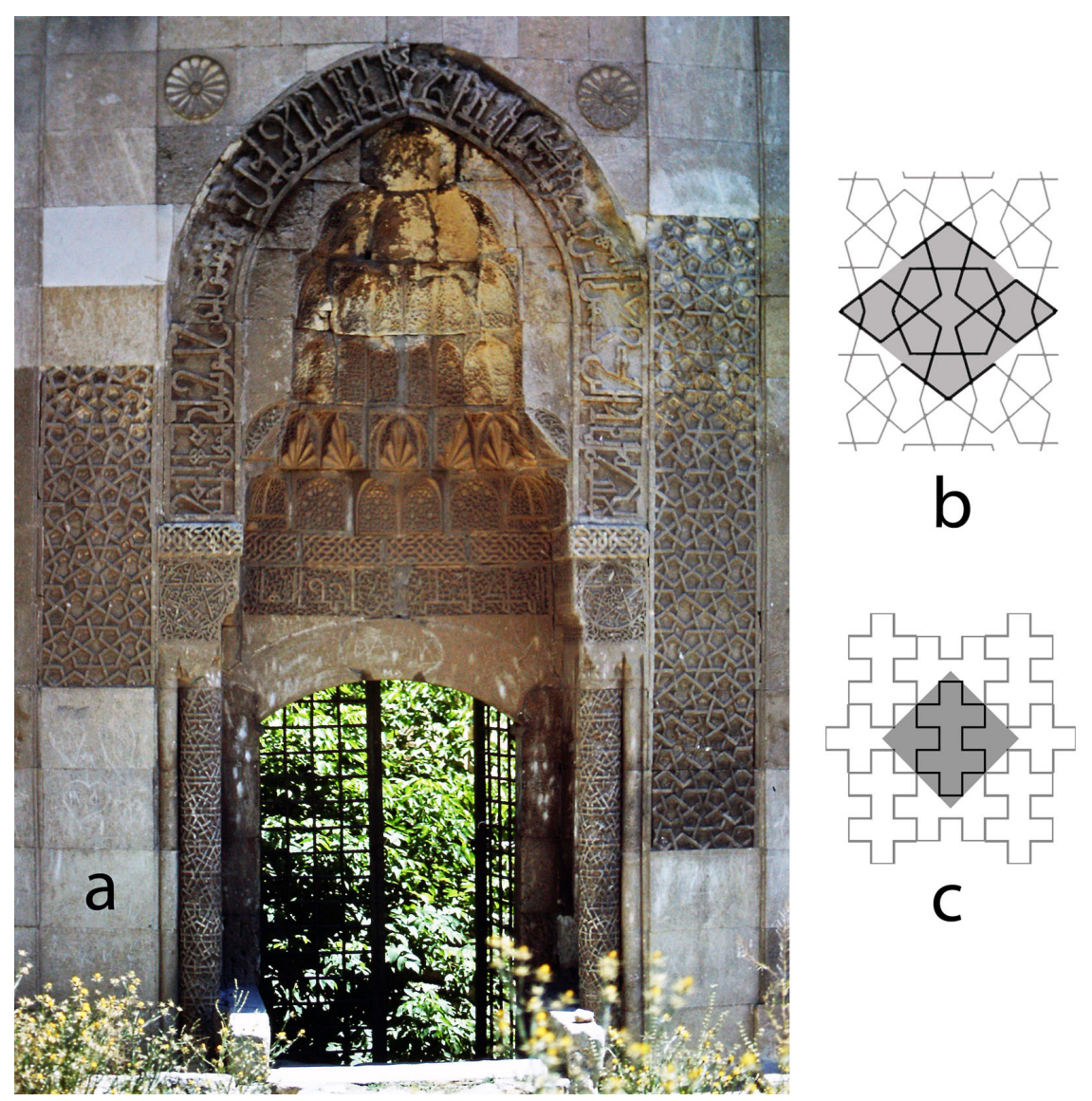

Figure 6. a) The entrance door of the Nene Hatun Mausoleum in Tercan, Erzincan, Turkey. b) The unit cell (highlighted) of the ornament observed on both sides of the portal. It belongs to the group c $2 \mathrm{~mm}$. c) For comparison, a graphically simpler ornament, also of the group c2mm, which is located in Sirçalı Mescit and Sırçalı Medrese, Konya, Turkey [11].

\section{Results}

In Figure 2 we have seen the distribution of symmetry groups of the artworks, belonging to five different cultures, the Eastern Roman, Armenian, Arabs of the Middle East (ME), Great Seljuks and Rum Seljuks. In all of them, we notice that the ornaments with the rotational order $n=1$ and 3 are quite rare, while fourfold symmetry is predominant throughout. The Eastern Roman artwork tends to emphasise patterns with low symmetry. In the patterns of Eastern Romans and Armenians (Figures 2 $\mathrm{a}$ and $\mathrm{b})$, there is almost no sample with sixfold symmetry $(\mathrm{p} 6 \mathrm{~mm})$. In contrast, the other three cultures with Islamic background (Rum and Great Seljuks and Middle East Arabs, Figures 2 c-e) show a strong occurrence of this symmetry group ( $p 6 \mathrm{~mm}$ ). Additionally, the groups $p 2 \mathrm{~mm}, \mathrm{c} 2 \mathrm{~mm}$ and $p 4 \mathrm{~mm}$ occur often in Seljuk and Arab artwork. In the following, we compare the specific pattern of distributions of artworks across these 17 symmetry groups to evaluate the dissimilarity between the cultures.

To measure dissimilarity between two cultures $X$ and $Y$, we used the Euclidean distance $\delta_{X, Y}$. It is the straight-line distance between $X\left(x_{i}\right)$ and $Y\left(y_{i}\right)$ in the $n(=17)$ dimensional Euclidean space:

$$
\delta_{X Y}=\sqrt{\sum_{i=1}^{n}\left(x_{i}-y_{i}\right)^{2}} .
$$

The components $x_{i}$ of the vector $X$ are given in Figure 2. We perform this operation for all paired combinations and obtain 25 distance values, which are combined in a matrix of the size $5 \times 5$. Since the distance between $X$ and $Y$ is the same as that between $Y$ and $X$, this procedure results in a symmetrical matrix with 10 independent distance values, listed in Figure 7. 
The Euclidean distance values reflect the dissimilarities between the cultural groups, so that the diagonal values of the matrix are zero. We observe a small dissimilarity between the two Seljuk groups and the Arab artwork (values 10, 14 and 20). A fair dissimilarity is found for the Eastern Roman artwork in relation to the work of the Great Seljuks (34), the Rum Seljuks (36) and the Arabs (40). In other words, Eastern Roman works of art are more similar to Armenian practice (29) than to the works of the Seljuks and Arabs. Technically, Eastern Roman works of art stand in a more or less favourable relationship to the works of the other 4 cultures, depending on how the sixfold-symmetrical patterns $(p 6, p 6 \mathrm{~mm})$ appear. The stronger presence of these symmetry groups leads to stronger dissimilarity values with the Eastern Roman group.

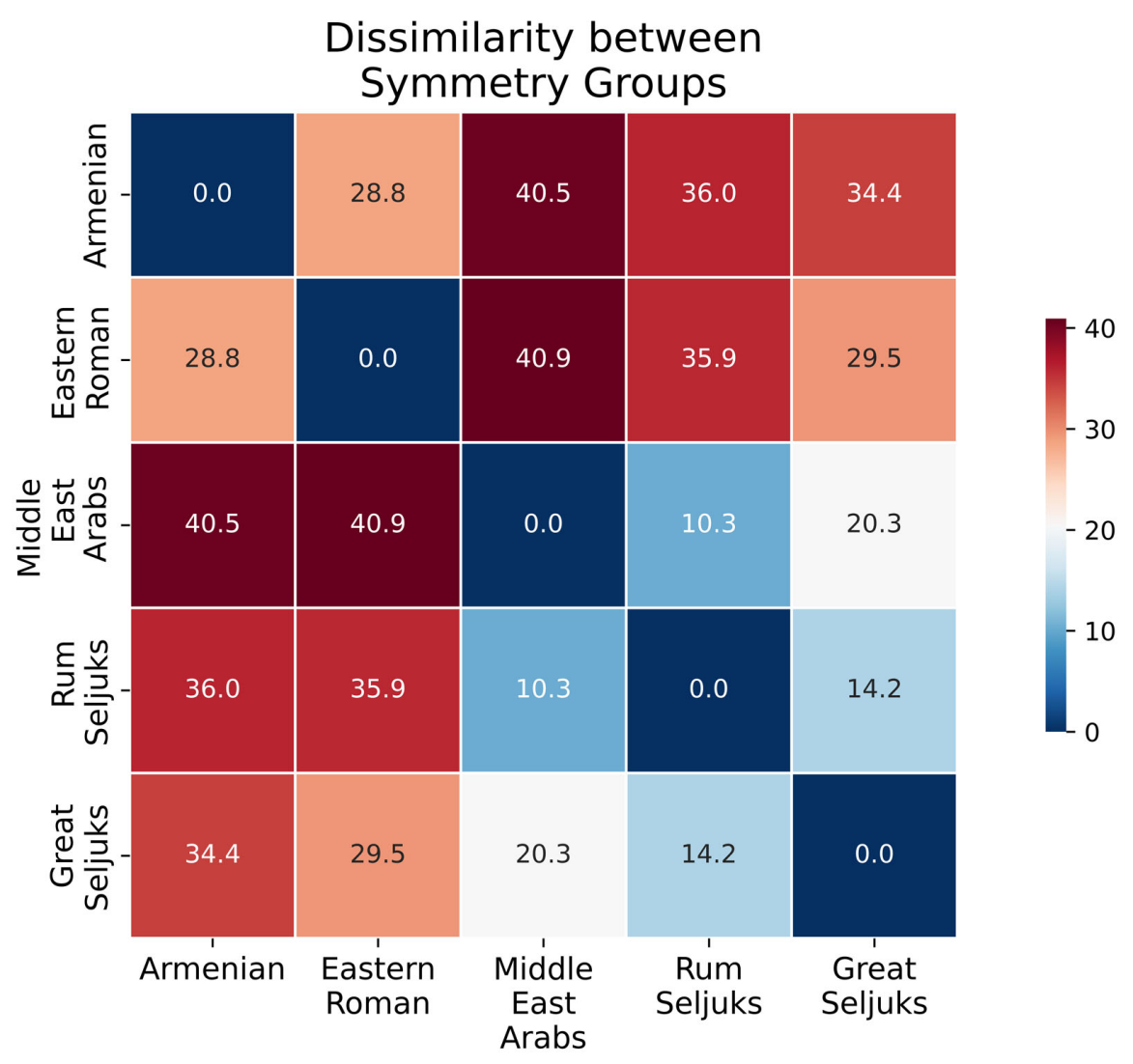

Figure 7. $5 \times 5$ matrix representing all pairwise dissimilarities between five cultures. The Euclidean distance was used as a measure of dissimilarity. The numbers within each cell indicate the distance value (in arbitrary units) between the corresponding pairs. Blue to red colours encode the strength of the correlation, as shown in the colour map.

Although this matrix contains all information about the dissimilarity relationships between all pairs of 5 cultures, it is relatively difficult to obtain an intuitive understanding of the general dissimilarity relationship between them, as this task amounts to taking into account 10 independent dissimilarity values simultaneously. To simplify the task, we have used the multi-dimensional scaling (MDS) method [12]. MDS is generally used to provide a summary visualisation of large dissimilarity matrices by transforming observed dissimilarities as closely as possible on the distances between the nodes. The specific arrangements of the nodes and the resulting distances between the nodes on a two-dimensional surface facilitate the understanding of the correlation matrix. We conducted a two-dimensional metric MDS analysis using the sklearn (version $=0.23 .1$ ) implementation in Python. Metric MDS is performed by iterative minimisation of a cost function called stress. Stress consist of the squared difference between dissimilarity values (as they entered into the algorithm) and the Euclidean distances between the coordinates of the nodes (the output of the algorithm). Minimising 
the stress-cost function results in the distance between the nodes reflecting as closely as possible the dissimilarity values entered into the algorithm [12].

The Eastern Roman artwork occupies a unique position among the works of other civilisations. Ornaments with $n<3$ are more common than those with $n>3$, as shown in Figure 2. Ornaments with $n=3$ do not exist, and those with $n=6$ are extremely rare. The cumulative value of the Euclidean distances with all neighbours is highest for the Eastern Roman and Armenian cultures (Figure 7), indicating low interactivity. The lowest value for the total Euclidean distance is found for the Seljuks. Great Seljuks had great ties with their descendants, the Rum Seljuks. The Seljuk civilisation with the most influential relations with the neighbours, have created works of art that are the most favourable example for the others. This also means that the Seljuks are the ones who are most influenced by their neighbours with long cultural history.

Figure 8 presents the resulting MDS diagram. A close group of Arabs from the Middle East, Great and Rum Seljuks indicates a small dissimilarity in the symmetry groups of their artwork. On the other hand, Eastern Roman and Armenian artworks are further away from this cluster, indicating a relatively high dissimilarity in the symmetry distribution of their practices. However, the dissimilarity between these two cultures is not so strong and does not form a cluster as densely packed as the former.

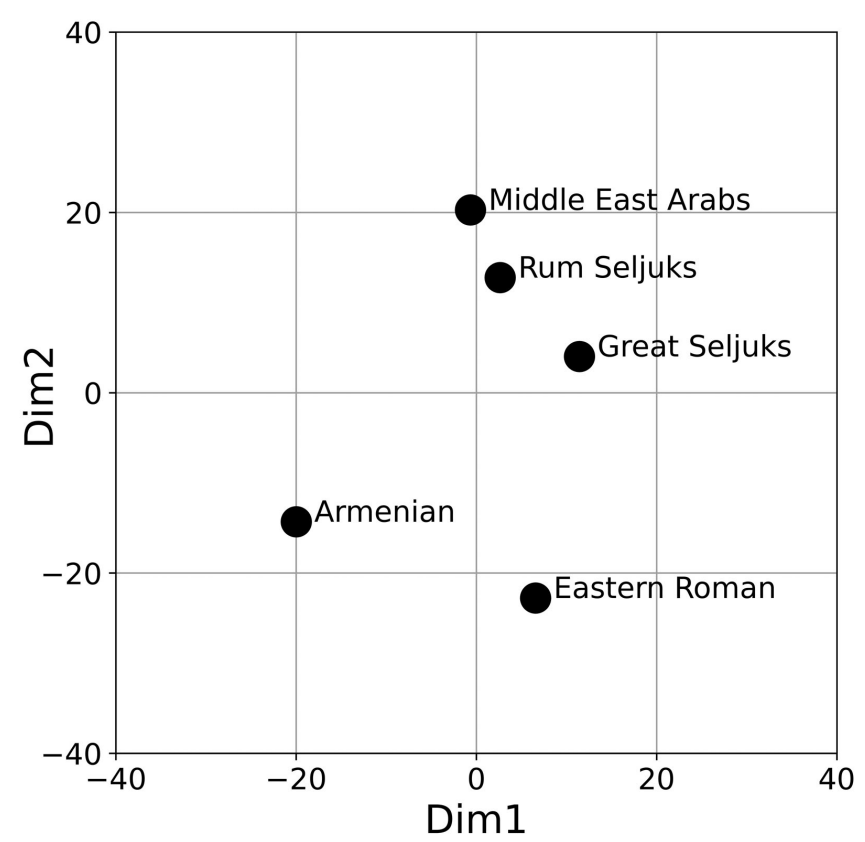

Figure 8. Visualisation of the Euclidean-distance matrix of Figure 7 with the method of MDS with two dimensions. Dim1 and Dim2 are the axes (arbitrary units) of the two-dimensional space generated by the analysis. Each node (black points) corresponds to a culture, and the distances between them represent their dissimilarity. High dissimilarity values between cultures, indicated by red colours in the previous figure, result in the corresponding nodes being far away from each other, while low dissimilarity values result in the nodes being closer together.

Next, we aimed to understand the dissimilarity between ornaments (shown in Figure 7) using two explanatory variables consisting of the geographical and religious distances between these five cultures. Geographical proximity measures the physical distance between the cultural capitals of these civilisations. This is motivated by the fact that geographical distance between different civilisations can be a decisive factor that facilitates or hampers their interactions, resulting in either more or less dissimilarities in the artworks created. On the other hand, the religion factor captures whether two civilisations categorically share the same religious background, regardless of their geographical distances. Artists and craftsmen who interact preferentially between civilisations with the same religious background could lead to smaller dissimilarity in the artworks generated. 
We therefore calculated two new dissimilarity matrices corresponding to geographical and religious dissimilarity. As for geographical proximity matrix, we used Yerevan (Armenians), Istanbul (Eastern Roman), Cairo (Middle Eastern Arab), Konya (Rum Seljuks) and Isfahan (Great Seljuks). Measuring the distances between all pairs of capitals results in the geographic distance matrix shown in Figure 9a. The correlation (Pearson correlation) between this geographical proximity matrix and correlation matrix of the symmetry groups has a small negative value $(r=-0.18)$, indicating almost no contribution of geographical distance to the dissimilarity relationships of artworks.

The religious proximity is used as a second explanatory variable. This variable categorically coded whether or not two civilisations had the same religion. This is shown for all pairwise comparison in the form of matrix in Figure 9b. The values here indicate whether a particular pair of civilisations share the same (blue colour) religious background or not (red colour). The correlation between the religious proximity matrix and the correlation matrix of the symmetry groups was high $(r=0.83)$ suggesting that the dissimilarity of artworks between the five different cultures could at least partially be explained by the religious background of these cultures.

We subjected this investigation to statistical analysis using a simple linear regression model and used the matrices for geographical (Figure 9a) and religious proximity (Figure 9b) as explanatory factors to model the observed dissimilarity between artworks (Figure 7). For this analysis, we discarded diagonal and duplicate values (resulting from the symmetrical organisation of the matrices). The regression model was significant $(\mathrm{F}=9.07, \mathrm{p}=0.014$, see Table A1 in Appendix) and returned a significant contribution for the religious proximity factor (regression coefficient: 0.8481, $\mathrm{p}=0.004$ ) whereas the geographic distance factor (regression coefficient: $0.006, p=0.976$ ) made no contribution to the dissimilarity of art works.
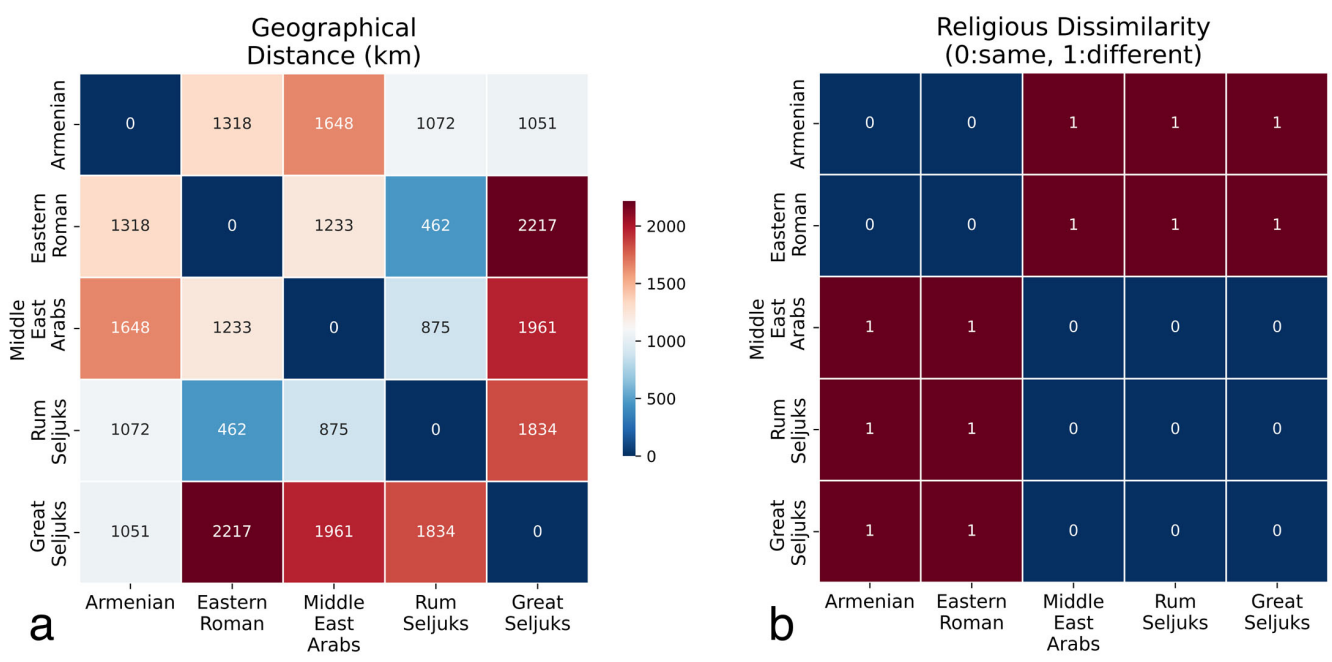

Figure 9. a) Geographic proximity matrix encoding the physical distance between the cultural capitals of 5 civilisations. As capitals we have used Yerevan, Istanbul, Cairo, Konya and Isfahan. b) The religious proximity matrix, which contains two categorical values. They indicate whether the corresponding pair of cultures have the same (red colour) or different (blue colour) religious background.

\section{Discussion}

Our results provide evidence in line with a strong interaction between the Arab and the Seljuk artwork. Our analysis shows that this strong similarity (weak dissimilarity) is largely due to the common religion Islam and that the influence is asymmetrical and ranges from Arab to Seljuk culture. The Great Seljuks had already converted to Islam when they entered Persian territory from the east. They lived mainly south of the Caspian Sea, occupied Baghdat and made Isfahan their capital. They mainly built religious buildings with characteristic ornaments [27,33]. The battle of Manzikert in 1071 was a decisive victory of the Seljuks over the Eastern Roman army, and thus there was no longer any obstacle for the Seljuks to invade Anatolia. After the assassination of the Seljuk leader Alpaslan, his 
nephew Suleyman made this move with his Turkmen followers. Around 1080 they came west as far as Nicaea and made the city the capital of their newly founded Rum Seljuk Sultanate. A few years later, in 1097, the capital had to be moved to Iconia under the influence of the invading crusaders [38]. The Rum Seljuks brought their Perso-Islamic culture with them which was mixed with some Central Asian habits. They created a mixture with the existing Christian tradition of Romans, Greeks, Armenians and Syriacs of Asia Minor. Meinecke is a specialist of the Seljuk art and architecture scene [39]. He reports that the earliest creation of the Seljuks goes back to the year around 1200. The Seljuks were creative peoples, however, their art production began 100 years later than their settlement in Anatolia. Between 1100 and 1200 the Sultanate of Rum was busy fighting off their former allies, the Danishmends. They also fought against the crusaders and Byzantium until their creativity flourished after 1200.

The Mongols gradually moved from east to west and arrived in Persian territory around 1200. They destroyed all existing facilities they encountered. It is conceivable that under the influence of the invading Mongols there was a strong emigration of peoples from countries south of the Caspian Sea and Mesopotamia to Anatolian prairies. This migration of peoples might have triggered the artistic creation of the Rum Seljuks. The brilliant rule of the Seljuks lasted until 1243, and after the Mongol defeat the sultanate disintegrated into small emirates. Yet, their craftsmen continued with their creation of ornaments until about 1400 .

The Seljuk motifs may be very similar to their Persian and Christian counterparts from Anatolia. Our method is insensitive to the local characteristics of the ornaments, we analyse the two-dimensional global symmetry that results from the assembly of the unit cells or motifs, taking into account the correct symmetry rules. Exactly these symmetry properties, which are used by the Seljuks, are almost identical to those of the Arabs. Also the creation of the Seljuks has fair similarity with the Armenian creation, while Armenian art emphasises above all the group $4 \mathrm{~mm}$.

There is a considerable overlap between Eastern Roman and Armenian art, which we attribute to their social coexistence. During the years of the Byzantine Apogee, until 1071, the defeat in Menzikert, there was a movement of Armenians into the eastern Roman Empire [41]. Some came voluntarily, others by force. The advance of the Umayyads into Armenian territory was the main event that triggered this migration. During these years, a large part of the Roman army consisted of Armenians. They often became high-ranking military men, even the best generals in Eastern Roman history. Many Armenians acquired intellectual and prominent positions in the Empire, they became politicians in the imperial rule and even emperors, such as Heraclius, Photios, Basel II, Nikephoros II Phokas, to name a few. Up to a dozen emperors of the Byzantine Empire were at least partially of Armenian origin in the period 582-1071. The devastating earthquake during the reign of Basel II destroyed the dome of the Agia Sofia Church in Constantinople. Trdat the Architect from Ani was invited for the repair [42]. Leo the Mathematician, John the Grammarian or Photios the Patriarch, all Armenians, were employed at the university in the Magnaura Palace. John the Grammarian and Theophylactus, together with Photios, were both Patriarchs of the Greek Orthodox Church. This imperial period had the reputation of being the Macedonian Renaissance or the Golden Age of the Macedonians. Some Armenian Emperors had an Armenian accent. But they ruled as Roman statesman with Greek culture, enriched with a touch of Eastern mysticism. In short, several leading figures in Byzantium were of Armenian decent. Therefore the weak dissimilarity in their creativity is not surprising.

Our analysis may be subject to some errors which may have affected the results. Firstly, the sources we have used may have neglected or overestimated some patterns. These are no systematic errors. Secondly, the fact that we have misinterpreted the archive material may be another source of error, which is also not systematic. Therefore, the results can only be influenced - if at all - by chance. Most importantly, the process of classification and the associated assumptions may have influenced the results in a systematic way. By neglecting or respecting the colour or interlacing, low symmetry is transformed to high symmetry and vice versa. Although systematic, all patterns of five cultural groups would be equally influenced by this process. Therefore, this practice does not affect the final conclusions. 
We have demonstrated the possibility of applying mathematical tools to the cultural treasures of different civilisations. In fact, we have found several links between these groups, which are otherwise known to specialised historians and art historians. We were able to find some obvious connections between peoples, but we see that the methods we use have the potential to uncover some hidden connections.

\section{Acknowledgments}

One of us (ME) thanks Fatma Erbudak for her support at every stage of this study. This research received no external funding.

\section{References}

1. Pólya, G. Über die Analogie der Kristallsymmetrie in der Ebene. Z. Kristall. 1924, 60, 278-282. https:/ / doi.org/10.1524/zkri.1924.60.1.278

2. Speiser, A. Die Theorie der Gruppen von endlicher Ordnung: mit Anwendungen auf algebraische Zahlen und Gleichungen sowie auf die Kristallographie; Julius Springer: Berlin, Germany, 1923.

3. Müller, E.A. Gruppentheoretische und strukturanalytische Untersuchung der Maurischen Ornamente aus der Alhambra in Granada. PhD Thesis University of Zurich: Zurich, Switzerland, 1944; El estudio ornamentos como applicatión de la teoría de los grupos de orden finito. Euclides (Madrid) 1946, 6, 42-52. Publishers home page https:/ / www.worldcat.org/title/euclides/oclc/924470145?referer=di\&ht=edition/.

4. Wood, E. Vocabulary of Surface Crystallography. J. Appl. Phys. 1964, 35, 1306-1312.

5. Macgillavry, C.H. Symmetry Aspects of M.C. Escher's Periodic Drawings; Bohn, Scheltema \& Holkema: Utrecht, Netherlands, 1976.

6. Washburn, D.K.; Crowe, D.W. Symmetries of Culture: Theory and Practice of Plane Pattern Analysis; University of Washington Press: Washington D.C., USA, 1991. https://doi.org/10.1080/00029890.1991.12000774.

7. Erbudak, M. Symmetry analysis of the floor ornaments of the San Marco cathedral in Venice. Heliyon 2019, 5, e01320. https://doi.org/10.1016/j.heliyon.2019.e01320.

8. Erbudak, M.; Kyurkchyan, A. Armenian, Byzantine and Islamic Ornaments - Influences Among Neighbours; Kyurkchyan: Yerevan, Armenia, 2019. https://doi.org/10.3929/ethz-b-000394011.

9. Kyurkchyan, A. Armenian Block Printing Fabric; Kyurkchyan: Yerevan, Armenia, 2016. Publishers home page http:/ / www.kyurkchyan.org.

10. Kyurkchyan, A. (Author); Khatcherian, H.H. (Photographer), Armenian Ornamental Art; Craftology: Yerevan, Armenia, 2010. Publishers home page http:/ / www.craftologyco.com.

11. Erbudak, M. Mathematical Classification of Rum Seljuk Ornaments. Symmetry: Culture and Science 2020, 2, 177-198. https://doi.org/10.26830/symmetry_2020_2_177.

12. Kruskal, J.B. Multidimensional scaling by optimising goodness of fit to a nonmetric hypothesis. Psychometrika 1964, 29, 1-27. https:/ / doi.org/10.1007/BF02289565.

13. Mansel, P. Constantinople; St. Martin's Press: New York City, USA, 1996.

14. Hughes, B. Istanbul; Weidelfeld \& Nicolson: London, GB, 2017.

15. Müller-Wiener, W. Bildlexikon zur Topographie Istanbuls; Ernst Wasmuth: Tübingen, Germany, 1977.

16. Perry, D.M. Sacred Plunder; Penn. State Univ. Press, Univ. Park, Penn. USA, 2015. https://doi.org/10.5860/choice.191747.

17. Kaldellis, A. Romanland: Ethnicity and Empire in Byzantium; Harvard University Press: Cambridge, Mass., USA, 2019.

18. Norwich, J.J. A History of Venice; Random House: Ney York, U.S.A., 1989.

19. Il Manto di Pietra della Basilica di San Marco a Venezia; Vio, E., Ed.; Cicero: Venice, Italy, 2012.

20. Bruyère, A. Sols: Saint-Marc, Venise; Imp. Nation.: Paris, France, 1989.

21. Fregonese, L.; Monti, C. L'ortofoto del pavimento tessulare di San Marco a Venezia. In Ref. [19]; pp. 29.

22. Jones, L. Between Islam and Byzantium: Aght'amar and the visual construction of medieval Armenian rulership; Ashgate Publishing: Aldershot, England, 2007.

23. Khatcherian H.H.; Kyurkchyan A. Armenian Ornamental Script; Craftology: Yerevan, Armenia, 2012. 
24. Armenian Cilicia; Hovannisian, R.G., Payaslian, S., Eds.; UCLA Armenian History and Culture Series: Historic Armenian Cities and Provinces; Mazda Publishers: Costa Mesa, CA, USA, 2008.

25. Erbudak, M.; Kyurkchyan, A. Scientific analysis of Armenian medieval ornamentation. Iran and the Caucasus 2020, in print.

26. Gutas, D. Greek Thought, Arabic Culture; Routledge: London, GB, 1998. https:/ / doi.org/10.4324/9780203017432.

27. Bonner, J. Islamic Geometric Patterns; Springer: New York City, USA, 2017. http:/ /dx.doi.org/10.1007/978-1-4419-0217-7/.

28. Wichmann, B. Symmetry in Islamic Geometric Art. Symmetry: Culture and Science 2008, 19, 95-112.

29. Clévenot, D.; Degeorge, G. Décors d'Islam; Éditions Citadelles et Mazenod: Paris, France, 2000.

30. Wichmann, B. http://www.tilingsearch.org/FirstUsage.html. Consulted on June 12, 2020.

31. Abas, S.J.; Salman, A.S. Symmetries of Islamic Geometrical Patterns; World Scientific: Singapore, 1995. https://www.worldscientific.com/doi/pdf/10.1142/9789814335942_fmatter.

32. Critchlow, K. Islamic Patterns; Thames and Hudson: London, GB, 1976. https: archive.org/details/IslamicPatterns_201805/page/n1.

33. Hutt, A.; Harrow, L. Iran I; Scorpion Publications: London, GB, 1977.

34. Başan, A. The The Great Seljuks: A History; Routledge: London, GB, 2010.

35. Hattstein, M.; Delius, P. Islam, Kunst und Architektur; Könemann: Köln, Germany, 2000.

36. Makowicky, E. Symmetry, De Gruyter; Berlin: Germany, 2016.

37. Schneider, G. Geometrische Bauornamente der Seldschuken in Kleinasien; Dr. Ludwig Reichert: Wiesbaden, Germany, 1980.

38. Mecit, S. The Rum Seljuqs: Evolution of a Dynasty; Routledge: London, GB, 2014.

39. Meinecke, M. Fayencedekorationen Seldschukischer Sakralbauten in Kleinasien Vol. I; Verlag Ernst Wasmuth: Tübingen, Germany, 1976.

40. Bulut, B. Selçuklu Çizgileri: Anadolu Selçuklu Geometrik Kompozisyonları; Inkilab Basım Yayım: Istanbul, Turkey, 2020.

41. Goodyear, M. Incide and Outside the Purple: How Armenians Made Byzantium. Armstrong Undergraduate Journal of History 2016, 6, ISSN 2163-8551. https:/ / digitalcommons.georgiasouthern.edu/aujh/vol6/iss2/2/.

42. Maranci, C. The Architect Trdat: Building Practices and Cross-Cultural Exchange in Byzantium and Armenia. The Journal of the Society of Architectural Historians 2003, 62, 294-305.

https://www.jstor.org/stable/3592516?seq=1\#metadata_info_tab_contents.

Appendix

Table A1. Regression Analysis

\begin{tabular}{|c|c|c|c|c|c|c|}
\hline Dep. Variable: & \multicolumn{2}{|l|}{ dist_sym } & \multicolumn{3}{|c|}{ R-squared: } & 0.687 \\
\hline Model: & \multicolumn{2}{|l|}{ OLS } & \multicolumn{3}{|c|}{ Adj. R-squared: } & 0.598 \\
\hline Method: & \multicolumn{2}{|c|}{ Least Squares } & \multicolumn{3}{|c|}{ F-statistic: } & 7.681 \\
\hline Date: & \multicolumn{2}{|c|}{ Thu, 10 Sep 2020} & \multicolumn{3}{|c|}{ Prob (F-statistic): } & 0.0172 \\
\hline Time: & \multicolumn{2}{|l|}{$11: 27: 42$} & \multicolumn{3}{|c|}{ Log-Likelyhood: } & -8.3823 \\
\hline No. Observations: & \multicolumn{2}{|l|}{10} & \multicolumn{3}{|l|}{ AIC } & 22.76 \\
\hline Df Residuals: & \multicolumn{2}{|l|}{7} & \multicolumn{3}{|l|}{ BIC: } & 23.67 \\
\hline Df Model: & 2 & & & & & \\
\hline \multirow[t]{2}{*}{ Covariance Type: } & \multicolumn{6}{|l|}{ nonrobust } \\
\hline & coef & std err & $\mathbf{t}$ & $P>|t|$ & {$[0.025$} & $0.975]$ \\
\hline dist_geo & -0.0122 & 0.216 & -0.056 & 0.957 & -0.523 & 0.499 \\
\hline dist_rel & 0.8262 & 0.216 & 3.823 & 0.007 & 0.315 & 1.337 \\
\hline constant & $1.388 \mathrm{e}-16$ & 0.211 & $6.56 \mathrm{e}-16$ & 1.000 & -0.500 & 0.500 \\
\hline Omnibus: & 0.024 & \multicolumn{2}{|c|}{ Durbin-Watson: } & 1.730 & & \\
\hline Prob(Omnibus): & 0.988 & \multicolumn{2}{|c|}{ Jarque-Bera (JB): } & 0.204 & & \\
\hline Skew: & 0.086 & \multicolumn{2}{|c|}{ Prob (JB): } & 0.903 & & \\
\hline Kurtosis: & 2.322 & \multicolumn{2}{|c|}{ Cond. No.: } & 1.23 & & \\
\hline
\end{tabular}

